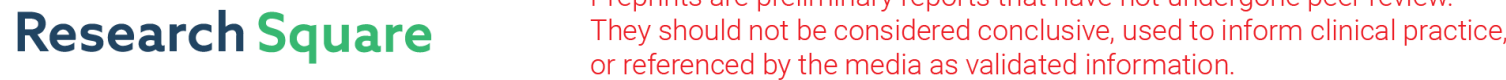

\section{Molecular insights on differential responses of antioxidant and pathogenesis-related genes in pigeonpea [Cajanus cajan (L.) Millsp.] to Fusarium wilt (Fusarium udum (L.)}

Koushik Biswas

Visva-Bharati

Roshan Kumar

Central University of Punjab

Avijit Tarafdar

International Crops Research Institute for the Semi-Arid Tropics

Vipin Gupta

University of Delhi

Nirjara Singhvi

University of Delhi

Parthadeb Ghosh

University of Kalyani

Mamta Sharma

International Crops Research Institute for the Semi-Arid Tropics

Sunil Pabbi

Indian Agricultural Research Institute

Pratyoosh Shukla ( $\sim$ pratyoosh.shukla@gmail.com)

Maharshi Dayanand University Rohtak https://orcid.org/0000-0002-9307-4126

Research article

Keywords: Fusarium udum, defense, pigeonpea, tolerance, gene expression, disease incidence

Posted Date: October 25th, 2019

DOI: https://doi.org/10.21203/rs.2.16464/v1

License: (c) (i) This work is licensed under a Creative Commons Attribution 4.0 International License. Read Full License 


\section{Abstract}

Background: Pigeonpea [Cajanus cajan (L.) Millsp.] is a major dietary protein source to a large vegetarian population in the world. However, Fusarium wilt (FW) caused by Fusarium udum Butler (FU) is one of the challenging factors to pigeonpea production. FW resistance in pigeonpea is restricted to specific agro-climatic zones. Therefore, exploring a superior pigeonpea genotype from landraces or local cultivars cultivated in various rural regions and validating its resistance response at biological and molecular level could be an alternative to crop improvement program. The present study was carried out to identify superior genotypes of pigeonpea through selection of innate resistance to FW using different biological and molecular approaches.

Result: Five distinct genotypes of pigeonpea along with well-known one resistant (ICP2894) and susceptible (ICP2376) control were selected on the basis of percentage of FW disease incidence from three different states of India after an extensive survey work. Among them, Richa had shown very less FW incidence (10.0\%) under genotype evaluation study and was further selected for experimental validation at molecular level for its innate resistance to FW. Molecular characterization and expression profiling of biotic stress responsive genes representing antioxidant enzymes (APX and SOD) and Pathogenesis related proteins (CHS and $\beta-1,3$-glucanase)families were carried out. Under FU challenged conditions in Richa, expression patterns of both $\mathrm{AO}$ genes found to be similar, while expression of both PR genes was gradually increased with inoculation time. Putative 3D protein structure of $\mathrm{CHS}$ and SOD were generated. Molecular docking with fungal effect or protein cellobio-hydrolase-c (CBH-C) also revealed that their role in blocking the hydrolytic activity of $\mathrm{CBH}-\mathrm{c}$ during pathogen invasion.

Conclusion: The obtained results of expression study and in-silico analysis showed that the higher level of induction of PR and AO genes and strong interaction of their putative proteins with fungal $\mathrm{CBH}$-cprotein established their antifungal activity conferring early plant defense responses to restrict the pathogen growth in resistant genotype Richa. Our study displaying a strong and combinatorial approach involving biological assay, molecular experiment and in-silico analysis to identify a superior genotype of pigeonpea resistant to FW across a major biogeographic region.

\section{Background}

The world population is continuously increasing and aggravate by 1 billion in 2050 to an estimated number of 9.6 billion from the present population of 7.2 billion (UNPAN, 2010) resulting in more requirement for food grains. With a long term planning for sustainable genetic improvement of major staple crops like rice, wheat and maize, it is necessary, at the same, time to gain a breakthrough in uninterrupted production of proteinaceous foods to strike a balance for reducing global hunger and malnutrition. Legumes, preferably pigeonpea, can be considered as a good alternative to easily available protein resource and offers a handful quantity of food proteins in Indian and African sub-continent with less cultivation care and low inputs. Pigeonpea belongs to family Fabaceae and is contributing by fulfilling the protein demand of $20 \%$ of global population and also serves as a major source of vitamins. In India, pigeonpea stands second after chickpea as the most essential food legume crop [1]. But now days, a major restraint in pigeonpea production is caused by biotic stresses wherein Fusarium wilt (FW) is considered as the most devastating disease followed by Sterility mosaic disease (SMD) and Phytophthora blight respectively. The former accounts for 30-100\% yield losses in pigeonpea genotypes vulnerable to this disease [2].

Assessment of the effect of any disease on yield of a crop with the help of a complete survey is pre-requisite for preparing rational disease management program. The system biology approach encompasses that the impact of biotic stress especially pathogen attack in combination with other variable abiotic stress factors leads to the molecular fine tuning of the degree of resistance, tolerance or susceptibility on a specific host plant [3]. On the other hand, sources of resistance identified in one region do not necessarily perform with the same degree of resistance in other regions, thereby indicating pathogenic variability in the fungus [4]. Several new sources of resistance have been reported against FW but there are still a lot of probabilities of getting improved and potential germplasms or indigenous genotypes at regional/rural level by searching, collecting and evaluating such genotypes for better resistance by following standard inoculation method [5]. The present investigation of germplasm evaluation against FW also revealed the importance of studying epidemiology of wilt disease. The genetics of FW resistance and or tolerance in pigeonpea is still in an ambiguous mean, and many more genes are supposed to be involved from a single dominant gene to two complementary genes and there might even be involvement of multiple genetic factors [6]. The in-depth knowledge on genetics of resistance mechanisms in host plants and genomic insights of wilt causing pathogen Fusarium udum are equally crucial for the genesis of effective strategies for efficient transfer and stable function of such resistant genes into disease susceptible cultivars. A number of resistance sources of germplasm against FW were identified by screening various pigeonpea genotypes over the last two decades at national and international level. Some of these promising genotypes were effectively used in crop improvement programs [5-8].

The fabrication of defense molecules such as phytoalexins, phenylpropanoids; pathogenesis-related proteins (PRs) viz.chalcone synthases (CHS), chitinases, and $\beta$ - 1,3-glucanases have very imperative roles because of their direct attacking activity on fungal and insect structural components. Beside these, a large number of biotic stresses related cellular enzymes such as superoxide dismutase (SOD), catalases, peroxidases are overexpressed to get rid of the pathogenic entry [9]. Two PR protein associated enzymes, namely chitinase and $\beta$ - 1,3-glucanase were successfully extracted and purified by gel filtration from the fungal pathogen induced chickpea plant and their higher activity was further confirmed by inhibiting the growth of Fusarium oxysporum f. sp. Ciceris (Foc) and other phytopathogenic fungi [10]. The defense network response in chickpea 
plant against Foc was also established by highlighting the studies on confocal microscopy to trace pathogen invasion, various enzymatic assays to detect structural changes in plant cellular membrane and validation of defense responsive transcripts by qRT-PCR approach [11]. Microarray based genome wide transcriptional study in F. oxysporum f. sp. lycopersici (Fol) and Tomato mosaic virus (ToMV) induced Tomato plant revealed a strong homeostatic defense response where chitinase and other PR gene families displayed high-level positive regulation in terms of fold changes [12]. Molecular cloning and characterization of $\beta$ - 1,3-glucanase gene in wheat inoculated with the stripe rust pathogen demonstrated a high level of expression pattern of this gene under qPCR analysis [13].

Considering the economic importance of pigeonpea and severity of FW disease, the present study was conducted to explore the existence of host resistance in case of highly wilt tolerant pigeonpea genotypes. A preliminary screening of pigeonpea germplasms collected from different states of India against a highly virulent FU strain was performed to identify resistant/tolerant genotypes. Attempts were made to identify the defenserelated genes in tolerant genotype by implying molecular and in-silico approaches and thereby investigate their expression pattern through quantitative PCR (qPCR) during pathogen infection. The present report envisages an elaborative biological and molecular study to investigate the genetics of tolerance mechanism of some well-known defense responsive and antioxidant genes in pigeonpea against FW.

\section{Results}

\section{Survey and epidemiological study}

During the extensive survey in the period between October and January 2014-2015, 25 different villages/Tehsils from four major pigeonpea growing state of India viz. TN, MP, AP and WB were successfully covered to carry out epidemiological study and searching of new pigeonpea sources tolerant to FW from existing germplasms indigenously grown in the surveyed areas. The maximum number of areas was covered in MP because there is no such survey report found in this state, which is contributing around $10 \%$ of total pigeonpea production in India (Table 1). As per DI \%, the lowest DI \% (4.5\%) was observed in Perayambetti gate village of Dharmapuri district in TN, whereas the highest DI \% (26.0\%) was observed in Anjad village in Barwani district of MP, followed by Sanawad village of Khargaon district of same state (Figure 2). As stated earlier, the surveyed areas were maximally covered in MP where three districts (Dhar, Khargon and Barwani) displayed the highest level of epidemiological variation in terms of DI \% (Table 1). As per the overall disease incidence is concerned, all the four states had a wide range of variations in terms of disease epidemiology. The seed samples of pigeonpea were exclusively collected from Warrangal and Medak regions of AP where pigeonpea is cultivated abundantly. Some local genotypes cultivated in the high and less disease prone areas of MP had natural characteristics of showing extreme tolerance and susceptibility to FW respectively. Maximum types of seed genotypes were collected from major pigeonpea growing regions of MP viz. Dharampuri, Manawar and Kukshi villages of Dhar district. The pigeonpea seeds of a total number of eight unique genotypes were collected from three different states viz. MP, AP and WB (Table 2). The selective collection of seeds of different genotypes was truly accomplished based on epidemiological data where genotypes were mostly cultivated with a higher and lower level of disease severity.

\section{Stress treatment and screening for tolerance}

Out of seven genotypes used for resistance screening, only two genotypes, ICP8863 and Richa were found to be promising showing very low wilt incidence. In known FW resistant genotype ICP8863, only 3.33\% disease incidence was recorded. In genotype Richa, the disease incidence was $10 \%$ and was thus put into highly resistant category, whereas another genotype, Desi Nimar came under moderately tolerant genotype because of 23.3\% DI. All the remaining four genotypes, Parwati, Desi Tur, WB-20/105 and ICP2376 were found as highly susceptible to FW (Table 2).

\section{Identification and molecular characterization of biotic stress responsive genes from FU inoculated pigeonpea genotypes}

\section{In-silico study}

For in-silico analysis of biotic stress defence-responsive genes, a total of twelve diversified genes were initially screened as all of them are directly or indirectly involved in defense response in plants where some are falling under a specific class of functional gene family. Prior to multiple sequence alignment, all the selected sequences of a single gene were graphically aligned to understand the level of divergence and convergence within ortholog sequences. In case of CHS, the CDS region covered from 58-1227 nucleotides with a length of 1170 bases covering complete CDS sequence. In a similar way, full length CDS coverage in maximum orthologs of a given gene was sharply observed in case of isoflavone reductase (IFR), methionine sulphoxide reductase B2 (MSR), glycosyltransferase (GTF), chitinase, $\beta-1,3$-glucanase and osmotin genes. In another case, protease and ascorbate peroxidase (APX) genes have the full length CDS for single gene sequence, but major orthologs did not cover this region of target gene due to their short size (Table 3). Glutathione peroxidase (GPX) gene was found to have a lowest match in the CDS region (120 ntd.) from full length CDS of 648 bases. Further, superoxide dismutase (SOD) gene consisted the lowest CDS (649 ntd.) but only conserved 500 bases (1-500 ntd.) in ortholog sequence. Beside the graphical alignment of all gene accessions, multiple alignments were also performed using all mentioned orthologs of each gene to revalidate the conservation in CDS region. For above twelve gene sequences, the maximum conservation in terms of length was visually observed in the case of nine genes except osmotin, protease and IFR. The phylogenetic tree was constructed for selected nine gene sequences by taking only the full-length CDS region of each gene and partial CDS where the full-length sequence was not available at all. From the cladogram analysis of all selected phylogenetic trees, maximum number of accessions grouped with 
a target sequence in a single cluster were observed in the case of APX, SOD (as an antioxidant enzyme family) and CHS and $\beta-1,3-g l u c a n a s e$ (PR protein family) with a defined biological and molecular defense response against biotic and abiotic stresses. Therefore, these four genes were finally selected for further molecular experiments.

Reverse transcription polymerase chain reaction (RT-PCR)

After several optimizations of gradient scale in PCR for each transcript, the best annealing temperatures found to be reproducible for successful amplification were $52.6^{\circ} \mathrm{C}$ for $\mathrm{CHS}, 60.0^{\circ} \mathrm{C}$ for $A P X, 57.0^{\circ} \mathrm{C}$ for $\beta 1,3$ glucan and $S O D$. The desirable amplicons with expected size $(\mathrm{CHS} \approx 560 \mathrm{bp}$, $S O D \approx 400 \mathrm{bp}, A P X \approx 350 \mathrm{bp}$ and $\beta 1,3$ glucan $\approx 450 \mathrm{bp}$ ) were obtained respectively followed by analyses on $1.0 \%$ agarose/EtBr gel to ensure the successful molecular identification of these four defense responsive genes (Supplementary Figure 1A-D). The identification of these four genes was performed truly upto RT-PCR level as all the amplicons were derived from cDNA rather than genomic DNA showing that these are specific, intensified and unique bands of desired length. Therefore, our study ensured the presence of gene transcripts at mRNA level and was sufficient to authenticate their expression pattern by using real time PCR approach.

\section{Validation of FW stress responsive genes by $q R T-P C R$ in pigeonpea}

In this study, expression profiling of four defense-related genes in susceptible (ICP 2376) and resistant (Richa) genotypes of pigeonpea during FW development was determined through qPCR. In the comparative analysis of antioxidant gene expression in pigeonpea during FU infection, it was observed that both the genes, $A P X$ and $S O D$ were up regulated in inoculated plants irrespective to genotypes. In overall expression study, it was observed that the expression of the $S O D$ gene was relatively higher than $A P X$ gene in later stage of infection in susceptible genotype ICP 2376 . Although the expression levels were varied in different time points at 7DAI and 15DAl, the expression was differentially regulated by a combination of positive (ICP 2376) and negative induction (Richa) (Figure 3A). It can be hypothesized that the degree of antioxidant activity needs to be enhanced with the time of infection and it delayed to make a balance in hypersensitivity response in case of susceptible pigeonpea genotypes to Fusarium. In case of genotype Richa, the difference in APX gene induction (F.C- 2.42 to 1.73) in two different TP could be due to activation of anti-oxidative response immediately after the fungal attack and thereby decreased gradually as the fungus was restricted by other defense mechanisms of that genotype. After immediate enzymatic activation, SOD gene product might have accumulated in sufficient amounts to necessitate the switching off of the gene. The effect of FW pathogenicity stress on SOD gene expression in both genotypes was quite interesting which has shown a variable range of positive induction with a gradual increase with inoculation time in case of Richa whereas the trend for ICP2376 cv. was reverse, showing a slight decrease from 2.80 to 2.41 as TP extended up to 15 days (Figure $3 \mathrm{~A}$ ). Thus, it was confirmed that both genes of same functional family were induced immediately after the fungal attack, but the expression needed to extend as time of infection increased to sustain the susceptible genotype with maximum defense response whereas the resistant one can recover from the infection after some time and the $A P X$ gene came to its native state.

In case of comparative study of expression pattern between $\mathrm{CHS}$ and $\beta-1,3$ glucanase genes, these PR genes had a mix response in terms of induction in both susceptible and the new genotype with unknown HR functions. Initially, after increment of inoculation time, the $C H S$ gene in Richa was increasing its expression up to 5.03 fold from an initial level of 2.21 fold compared to the nearly stagnant expression in ICP 2376 (FC 1.79-2.09) confirming that the said enzyme gets involved in stimulating the initiation of defense response at ground level (Figure $3 \mathrm{~B}$ ). On the other hand, as the inoculation time increased from 7DAI to 15DAl, the relative expression of $\beta-1,3$ glucanase gene in ICP2376 is more or less constant with an apparent fold change (FC) of 2.40 to 2.89 (Figure 3B). In case of Richa, a continuous change in the inoculation time further accelerated gene activity by gaining induction up to 15.61 fold from FC- 7.47. The overall expression pattern of this gene in both genotypes had shown zigzag type model and it could be possibly explained by the fact that most gene expression is dynamic in nature which is not expected to be up-regulated in all points of factor.

\section{In-silico analysis and protein modelling}

To validate the transcript abundance in Fusarium inoculated pigeonpea genotype (Richa), the PCR purified products of partially amplified CHS (537bp) and SOD (361bp) genes were sequenced. The sequences were purified and submitted to GenBank under accession numbers MN095237 and MN095238. The partial gene sequences of CHS and SOD were translated to 179 and 120 amino acids (aa), respectively. The nucleotide sequences were compared with the other pigeonpea varieties and legumes. The sequence comparison of both showed $98.32 \%$ sequence identity with CHS from Phaseolus vulgaris [GenBank: X06411] and $97.51 \%$ identity with SOD from Cajanus cajan[Genbank: XM_020353639] respectively. The deduced amino acid sequences of both genes, CHS and SOD had predicted molecular weight of $19.26 \mathrm{kDa}$ and $12.15 \mathrm{kDa}$ respectively.

The target receptor protein Chalcone synthase (CHS), and Superoxide dismutase (SOD) were full length genes with 179 a.a. and 120 a.a. respectively. Chalcone and stilbene synthases, (Chalcone_synth; 62-78) is identified as the active site in CHS with Cys164, and active residue at 70. Whereas SOD has 2 active sites of Copper/Zinc superoxide dismutase signature 1 and 2 at regions 15-25 and 109-120 respectively. Protein sequences were analyzed for prediction of 2D and 3D model based on homology modelling. The 3D model selected for the study has the identity of $94.41 \%$ and $80 \%$ respectively for $\mathrm{CHS}$ and SOD which is much above the cut-off value of $30 \%$. The structure of $\mathrm{CHS}$ has 54 alpha helix and 3 beta sheets along with 2 beta hairpin loops. While SOD is composed of 4 alpha helix, 2 beta sheet and 2 beta hairpin loops (supplementary table

Page $4 / 17$ 
and figure). 3D model for both the proteins are present in homodimer state (Figure 4a, 4b). The stability of the structures can be confirmed by the presence of beta sheet in the secondary structure. Based on the physiochemical properties calculated using protPARAM server, the amino acid composition was analyzed (Supplementary Table 1) and both proteins were classified as stable protein based on its instability index (CHS: 28.02 and SOD: 5.66). SOD is considered as highly stable structure due to lowest instability index. Further Ramachandran plots were studied where $\operatorname{phi}(\varphi) / \operatorname{psi}(\psi)$ angles of the amino acid residues were $96.89 \%$ and $95.19 \%$ for CHS and SOD respectively (Figure $4 \mathrm{~d}$, $4 \mathrm{e}$ ) thereby proving the stability of both proteins. The QMEAN value was analyzed for the quality of 3D structure. The QMEAN scores for CHS and SOD are 0.84 and 0.85 respectively. The reliable 3-dimension structure lies between the range of $0.5-1$. The structure of fungal $\mathrm{CBH}-\mathrm{C}$ was also checked for stability. The instability score (39.12) and QMEAN value (0.61) confirms its reliability. The docking was done using FRODOCK (Figure 5a, 5b) and simulation was carried out using online server GRAMMX. Clashes/contact score was calculated for both the interaction models (Figure $5 \mathrm{c}$, $5 \mathrm{~d}$ ). The maximum correlation score was obtained for CHS i.e, 189394.84 and for SOD it was 1.59. CHS docking with CBH-c has the clash score of 20 and 138 contacts whereas SOD interacts with $\mathrm{CBH}-\mathrm{c}$ with 20 clashes and 179 contacts. $\mathrm{CBH}-\mathrm{C}$ bind more strongly with $\mathrm{CHS}$ as compared to SOD. In relation to the attack of $\mathrm{FU}, \mathrm{CBH}$ gene present in fungal cell can be considered as a potent factor for the synthesis of cellobiohydrolase and this cellular enzyme is secreted by fungi to degrade host plant cellulose through the discharge of cellobiose for the deployment of their pathogenic activities [27]. The present interaction study of both plant genes with FU-CBH gene could be correlated with the qPCR analysis where higher rate in fold change expression of CHS (7.47 at 7DAl to 15.61 at 15DAl) than SOD gene (2.41 at 7DAl to 2.61 at 15DAl) was observed. This can be concluded that the CHS gene transcript is more hyperactive than SOD with a tendency to release more number of functional proteins through translation process after pathogen inoculation and it could further functionally block the activity of $\mathrm{CBH}$ protein by making a strong binding affinity.

\section{Discussions}

Fusarium wilt is a vital ailment of pigeonpea and is realized to be the worst problem for cultivation of this crop in India [28]. The annual economic losses due to wilt in pigeonpea have been assessed at US \$ 36 million in India and the subsequent yield loss can also be increased up to $100 \%$ in susceptible cultivars [29]. So, it is necessary to find a way out in sustainable manner to prevent the disease in this crop. Among the different control measures, early diagnosis and control in the light of advancement of molecular technologies are quite promising. The importance of wide level of survey is not only related to epidemiology of a disease to understand, describe, compare and predict epidemic, but also make a chance to explore the most promising highly tolerant genotype/s against a particular disease from surveyed areas. From 1980 to till date, a number of surveys were carried out in different pigeonpea growing countries. The present survey-based study reported regional diversity of more than 25 pigeonpea-cultivated areas representing the major agro-climatic regions of India under pigeonpea production, which were found to be suitable for growing local genotypes/cultivars due to their potential nature of tolerance/susceptibility mechanism to FW. Taking into consideration of the most variable geographical region, MP represented a great diversification in disease incidence range from resistant to highly susceptible areas. As far as lowest disease epidemiology is concerned, TN was found to be the lowest disease prone state with no class as highly infested area and very highly infested area. Besides India, this disease was reported from East Africa and Malawi, where yield losses were reported to have crossed above $50 \%$ in some places. Yield losses in pigeonpea due to FW was also reported form countries like Bangladesh, Indonesia, Grenada, Myanmar, Mauritius, Nevis, Nepal, Venezuela, Trinidad and Tobago [30] This pathogen was also recorded for causing severe disease in the Southern Zambezia province under South Africa [31].

The study of exploration of pigeonpea genotypes to FW displayed an overall contrasting response for all selected genotypes. The experimental reference variety ICP-8863 displayed a negligible or near to zero level of symptoms (D.I-3.33\%) in one out of 30 plants as it is already reported for its best resistance mechanism against FW independent to environmental and geographical conditions. It is finally concluded that Richa was one of the most highly tolerant genotypes (\%D. I- 6.67) after ICP-8863 with a higher degree of tolerance potential and that could be due to specific morphological modification in the xylem vessel of the root system or targeted activation of some defense related proteins and transcription factors during fungal stress or due to both reasons. On other hand, Parwati was authenticated as one of the most susceptible among all experimental genotypes and it could be due to its weak defense system. Although ICP 8863 and ICP2376 were confirmed for their extreme resistance and susceptible characteristics, respectively in our experiment and were earlier validated so many times for these features [28, 32]. Therefore, these three genotypes viz. ICP 8863 , ICP2376 and Richa were picked for further molecular biology studies. In overall evaluation data, all the four classes of disease scales were fitted for selected genotype population. A number of efforts have been taken to find out the most potential genotypes or cultivars resistant against FW over time and pathogenic strains. First time observations on wilt resistance in pigeonpea was reported by Butler in 1908 [33]. Apart from this, 950 genotypes screened had shown zero resistance to FW with less than 10\% wilt incidence in 19 genotypes [29], 16 out of 31 pigeonpea cultivars screened were resistant to wilt with highest degree of resistance (2.15\%) in BWR 369 cultivar [34]; six cultivars were reported to be resistant to FW among 216 late maturing pigeonpea germplasm evaluated [7]; resistance screening in 976 genotypes, germplasm and breeding lines FW using wilt sick plot confirmed 92 genotypes resistant after a rigorous two years testing at Patancheru, India [35]. Another study on evaluation of new elite pigeonpea germplasm using wilt sick plots demonstrated a consistent rate of high level of resistance ( $\mathrm{DI}<20.0$ \%) in ICEAP-00040 genotype to FW reported in Kenya, Malawi and Tanzania [31]. 
For the identification, quantification and expression profiling of highly active plant defense responsive genes, proteins under enzyme group and in most cases, transcription factors and high throughput molecular techniques have been developed and customized day by day for their successful implication. In our current study, understanding of spatio-temporal expression of major defense responsive promising genes during pathogenesis and the study of different patterns of symptomatology based tolerance in various plant genotypes specific to various agro-climatic regions of India can provide the vital knowledge for crop improvement with well-developed tolerance mechanism. Higher plants directly defend a number of biotic and abiotic stresses with their broad range defensive mechanism, especially the production and accumulation of pathogenesis related proteins in plants in response to invading pathogen [36]. A wheat $\beta-1,3$-glucanase gene (TaGlu) induced by Puccinia striiformis (Pst) was cloned, characterized and qPCR analyses confirmed that the transcription of TaGlu was induced in both compatible and incompatible interactions [13]. In our present molecular biology study, the modified RNA extraction method is equally useful to extract stressed sample as well as fungal RNA with maximum reproducibility to trace their gene's functions and behaviour under various stresses imposed during pathogen attack [16]. By using isolated RNA from modified method, RT-PCR based detection of four genes belonging to AO enzyme and PR protein groups was performed and their successful amplifications made an inference that the genes are actively present in plant system during FW stress. The corresponding mRNAs were synthesized at the nucleus and circulated over cytoplasm followed by their translation to the consequent proteins or enzymes, which are directly or indirectly involved in defense response to significantly enhance their tolerance to pathogen attack. To precisely monitor the expression level of a gene at various stages, qPCR-based transcript profiling approach is highly adorable and the present comparative analysis of expression of $\mathrm{AO}$ genes with $\mathrm{PR}$ protein genes has revealed a variable mode of expression between susceptible and biologically validated resistant cultivars. It was also indicated that no significant differential induction has been located in case of SOD for both genotypes and $C H S$ for ICP2376. It can be concluded that these genes did not have any significant expression variation under FW stress by considering the varietal difference. Higher magnitude of transcript expression at the last TP confirms that the expression was specific to infection stage rather than gene and genotype. This may help the plant to cope with the deleterious effects of pathogen attack at early stage critical for later growth and development [37]. Comparatively, the imperative variations were observed in the case of $A P X$ and $\beta-1,3$ glucanase genes. An attractive finding of the present study is the differential expression of $\mathrm{CHS}$ gene activity in susceptible and resistant (biologically validated) pigeonpea genotypes whereas the induction level of $\beta-1,3$-glucanase activity was found increasing in Richa genotype under continuous pathogen load. Liu et al. [13] and Nagy et al. [38] also reported a similar type of expression behaviour of $\beta-1$, 3-glucanase gene induced by stripe rust pathogen Puccinia striiformis f. sp. Tritici in wheat and $\mathrm{CHS}$ gene with an induced response to pathogen infection in Norway spruce phloem respectively. It is known that plants possess inducible and constitutive defences. Structural analysis of PR-genes and antioxidant genes suggests that they are active in signalling cascade(s) that coordinate initial plant defense responses in order to impair pathogen growth. Besides, PR-gene products may have a function in plant development and therefore, be expressed in challenging but tolerant genotypes of pigeonpea plants, ready to detect any attack. Our results suggest that both mechanisms may be important for FU tolerance. The difference between tolerance and susceptibility depends on a number of internal and external factors of which early detection of pathogen is considered as prime factor.

The in-silico 3D structure was predicted for the proteins (CHS and SOD). The value of instability index (CHS: 28.02 and SOD: 5.66) indicated their high stability as a model. GMQE score value of CHS (0.99) and SOD (0.93) indicated the expected accuracy of the model from target template alignment and target sequence coverage. Higher GMQE value indicated higher reliability. QMEAN value provides estimate of 'degree of nativeness' of protein structural features in the model on a global scale. It ranges from -4 to 0 . Assessed QMEAN values, 0.84 and 0.85 for $\mathrm{CHS}$ and SOD respectively were within the acceptable range of high-quality model. Further validation and refinements of model were confirmed using Ramachandran plot. The phi $(\varphi) / p s i(\psi)$ angles of the amino acid residues revealed that both $\mathrm{CHS}$ and SOD proteins hold more than $90 \%$ amino acids in favoured region, thus considered accurate. Identified active site in CHS (Cys164), active-site nucleophile is reported to be crucial in polyketide formation and initiation series of decarboxylation, condensation, and cyclization reactions along with other amino acids [39,40]. SOD shield cells from ROS by catalysing the disproportionation of superoxide anion radicals into molecular oxygen and hydrogen peroxide. Predicted active site Copper/Zinc superoxide dismutase signature 1 and 2 at regions 15-25 and 109-120 contributes to stability of the framework and dimer assembly [41]. The maximum correlation between docking score were considered strongest protein-ligand interaction. Thus, both the CHS and SOD proteins bind with $\mathrm{CBH}-\mathrm{c}$ actively in order to block the functional activity.

\section{Conclusion}

The evaluation of the surveyed results revealed the feasibility of pre-screening of such genotypes falling under the first group (DI 0-10\%) for genetic diversity analysis and their potential association with FW tolerance. Both well-known pigeonpea varieties (ICP8863 and ICP2376) showed their similar mode of sensitivity to FU as reported earlier, where two genotypes from MP showed tolerance ability and two were very susceptible to FU stress. Therefore, Richa is considered here as the best performing highly tolerant genotype to FW based on evaluation of the overall survey and resistant screening results. Under molecular study, our aim was to identify promising genes and robust alleles for fungal disease resistance which can be further utilized for the development of crops challenging to FW infection. Therefore, we performed the molecular detection of four defenserelated genes through RT-PCR based approach and thereby quantifying their expression level by using qPCR technology. The $\beta-1,3-g l u c a n a s e$ under PR protein family is highly functional and $\mathrm{CHS}$ gene under polyketide synthase super family is moderately functional intolerant genotype rather than susceptible one. In another case, $A P X$ and $S O D$ under $A O$ group have also shown positive regulation to trigger and modulate resistance response with less variation in two extreme genotypes. The identification of such genes would be potentially used as molecular markers for 
screening resistance genes from pigeonpea as well as could be used for developing transgenic and/or improved pigeonpea varieties resistant to FW infection suitable under changing global climate.

\section{Methods}

\section{Survey of Pigeonpea growing areas of India}

Surveys were conducted in nine districts of major pigeonpea growing regions representing four different states of India viz. Andhra Pradesh (AP), Madhya Pradesh (MP), Tamil Nadu (TN), and West Bengal (WB). The surveys were carried out following random sampling method. Epidemiological study of FW in pigeonpea was performed by using following formula of Percent Disease Incidence (DI \%) -DI\% = Number of plants infected by wilt disease $\times 100 /$ Total number of plants observed. The DI \%was individually calculated for each plot by following the above formula. DI \% ofthree plots of a single field were summed up together to determine mean DI \%. The average value representing the overall DI \% for each village under survey was arranged in tabular format (Table-1). To understand the epidemiological intensity of the disease in each village under a particular surveyed district, the grading of the \% DI was further set into five categories (Figure-2).

\section{Collection of seed materials}

For exploring new pigeonpea genotypes/landraces resistant to FW and grown locally, during disease survey a parallel field survey was undertaken for a collection of seeds from apparently resistant genotypes/landraces in such areas (villages) where Fusarium wilt disease was observed naturally (Table-2). Seeds from a total of eight different pigeonpea genotypes/ landraces were collected. Among them six were exclusively the landraces or local cultivars cultivated by the farmer communities year after year. These landraces were not even exposed and used by the scientific communities or plant breeders to develop superior variety or to conserve their germplasm in regional or national institutes with a specific accession number. After getting permission and confirmation about their local name from the respective farmer communities, the seeds of a specific genotype were exclusively collected from a single plant which was selected based on growth, health and yield. The crop was identified informally by the main author and respective farmers', as the crop is well known and widely cultivated species.

\section{Plant growth conditions}

The apparently bold and healthy seeds of all collected pigeonpea cultivars/genotypes were surface sterilized using $0.1 \% \mathrm{HgCl}_{2}$ followed by three times washing with sterile water. The treated seeds were then sown in polythene bags filled with sterilized river sand and watered properly. The polythene bags were then kept cautiously in glasshouse maintained at $28-30 \pm 2^{\circ} \mathrm{C}$ with natural photoperiod conditions. The 7 days old seedlings were then used for pathogenicity test and other molecular studies.

\section{Inoculum preparation and pathogenicity test for germplasm screening}

The highly virulent strain of FU (ICFU 109) was initially inoculated in potato dextrose agar (PDA) media from slant culture. After seven days of incubation in PDA plate, the young FU culture with profuse conidia was further inoculated in PDB media. The FU inoculated broth culture was kept in an incubator-shaker maintained at $25^{\circ} \mathrm{C}$ with a continuous shaking of $120 \mathrm{rpm}$ for $6-7$ days. For screening of resistance and or tolerance level in pigeonpea genotypes against FU under controlled conditions, the root dip screening technique was used [4]. Conidial suspension of FU was diluted with sterile water to maintain a final concentration of approx $6 \times 10^{5} \mathrm{spores} / \mathrm{ml}$. Seven days old, seedlings of each genotype were carefully uprooted from germination trays and washed under running water. Root tips $(0.5 \mathrm{~cm}$ long $)$ of each seedling was cut off and dipped in the diluted inoculum suspension for 1-2 minutes for pathogen entry. A similar procedure was followed for experimental control where injured seedlings were treated with sterile distilled water. The inoculated seedlings were transplanted into six-inch pots filled with sterilized soil, sand and farm yard manure (FYM) in a ratio of 1:1:1. Each pot contained three plants and each genotype was transplanted into ten pots (three seedlings/pot). Five pots of each variety were considered as five replications for each time point (TP) of the experiment (5 replications $\times 2$ TP). The greenhouse was maintained at $25 \pm 2^{\circ} \mathrm{C}$ with natural light and dark condition. At two TPs i.e. 7 and 15 days after inoculation, the plants showing positive and negative wilt symptoms were fixed for data recording. To get the overall disease incidence, the percent of disease incidence was calculated by following formula:

[See supplementary files for formula]

Based on disease incidence, genotypes were categorized as tolerant/resistant ( $\leq 10.0 \%)$; moderately tolerant/resistant ( $>10.0-20.0 \%$; susceptible (>20.0-40.0\%) and highly susceptible (>40\%). At each TP the inoculated seedlings were removed from the soil, washed with sterile water, completely dried with tissue paper and quickly snap frozen in Liquid $\mathrm{N}_{2}$ followed by storing at $-80^{\circ} \mathrm{C}$.

Molecular characterization of defenseresponsive genes e against FW in pigeonpea

In-silico study for targeting stress responsive genes 
The aim of the present study is to find out some important and promising genes, which have a major biological role directly or indirectly related to defense response against biotic stresses mainly against fungal pathogens. Twelve genes were selected and corresponding nucleotide sequences with their accession numbers were retrieved from NCBI database. The information on plant sources, sequence length (bp) and length of coding sequences (CDS) were collected and tabulated (Table-3). The individual gene sequence was further subjected to blast to NCBI database (http://www.ncbi.nlm.nih.gov/blast) to get best hit ortholog sequences belonging to the Fabaceae crop family where the maximum cut off was fixed upto $80 \%$ [14]. All the identified gene sequences from same family were retrieved and subjected to multiple alignments using MULTALIN program to identify the conserved region [15]. The CDS region, which was shared by common conserved region of maximum number of accessions was marked and selected to find out longest possible Open Reading Frame (ORF). The longest stretches of ORF sequence without any intermediate stop codon were subjected to amino acid translation using Expassy translate tools to get the putative protein sequences (http://web.expasy.org/translate/). The translated amino acid sequences were finally used as an input in protein motif finder tool to know whether translated amino acid sequences give the most stable target protein motif or not and for this Conserved Domains Database (CDD) was used (http://www.ncbi.nlm.nih.gov/cdd/). On the basis of obtained functional motif of each protein, the normal and special functional behaviour of said protein was figured out. The specific functions of the proteins were further validated with reported literatures to confirm whether they are actively involved in fungal or any other biotic stress response or not.

\section{Primer designing and constructing RT-PCR profile}

Oligonucleotide primer designing for RT-PCR experiment was performed for four defense responsive genes viz. Chalcone synthase and $\beta-1,3-$ glucanase representing pathogenesis related (PR) and Ascorbate peroxidase and Superoxide dismutase representing antioxidant (AO) gene families which were initially screened through in-silico based gene targeting study as discussed earlier. The online tool of Integrated DNA Technology (http://eu.idtdna.com/primerquest/home/index) was used to design the primers. Total RNA of good quality with adequate quantity from healthy and fungal stress imposed pigeonpea seedlings was isolated after a level of optimization of classical RNA isolation technique [16]

The experimental ImProm-IIT Reverse Transcription System (Promega, USA) was used to synthesize first-strand cDNA from isolated RNA. For each reaction, experimental RNA (up to $1 \mu \mathrm{g}$ ) was combined with the cDNA primer [Oligo (dT) 15 @ 0.5 $\mu$ g/reaction] in nuclease-free water to make a final volume of $5 \mu \mathrm{l}$ per RT reaction. All the subsequent reactions of RT-PCR were strictly followed as per manufacturer's instruction. The recommended temperature-time profile was followed after keeping the final $20 \mu \mathrm{RT}$ reaction in a thermal cycler. In the next step of PCR reactions, the cDNA mixture was further amplified by PCR (GenAmp, Applied Biosystems, USA) with $25 \mu$ of total reaction volume. As the calculated Tm values for all selected four primers were in the range between $52^{\circ} \mathrm{C}$ to $60^{\circ} \mathrm{C}$, the gradient scale was adjusted for individual gene by keeping five replicate reactions in different gradient blocks. After amplification, all samples were stored at $-20^{\circ} \mathrm{C}$ until further use. The PCR amplified products were gel electrophoresed (1.2\%), visualized with UV Trans-illuminator, and photographed using the Alpha Digi DocTM system.

\section{Expression profiling of FW stress responsive genes by qPCR in pigeonpea}

The cDNA were quantified using Nanodrop spectrophotometer (Thermo Scientific NanoDrop 2000C Technologies, Wilmington, USA) and the integrity of cDNA was checked by $1.2 \%$ agarose gel electrophoresis and ethidium bromide staining. For determining the expression profile for known PR and AO genes, qPCR study was conducted. The specific oligonucleotide primers for qPCR were designed by IDT tool (Table 4). IF4aInitiation component 4 a gene as most stable housekeeping gene in pigeonpea, the gene was considered as an internal standard for endogenous control [17]. The PCR reaction mixture was made by combining the following chemicals: 2x KAPA SYBR® FAST qPCR Master Mix (Wilmington, USA) @10 $\mu \mathrm{l}$, PCR primers (Forward and Reverse) @ 10 mM-1 $\mu$ l each, cDNA template 40 ng/ $\mu \mathrm{l}-5 \mu \mathrm{l}$ and PCR grade water-3 $\mu \mathrm{l}$. The qPCR was carried out by completing 30 cycles using LightCycler ${ }^{\circledR} 480$ Real-Time PCR System (Roche, USA) by following the standard cycles as mentioned in instruction manual. All the technical replications of qRT-PCR experiments were conducted in triplicate and repeated twice to consider two biological replications and each time the results did not vary. By utilizing the quantitative value of cDNAs, expression profiling of individual gene was quantified at variable stress conditions by using algorithms truly based on $2^{-\triangle \Delta C T}$ method [18].

\section{In silico characterization of stress responsive genes in correlation with fungal infection}

Out of four gene transcripts amplified in RT-PCR, two candidate genes namely chalcone synthase (CHS) and superoxide dismutase (SOD) representing PR and AO gene families, respectively were sequenced from both side (Xcelris Genomics, Gujarat, India). The obtained sequences were aligned and purified. To validate, the purified sequences of CHS and SOD were NCBI-BLAST and submitted into GenBank. The transcript sequences of both genes were analyzed at in-silico level. Gene predictions in CHS and SOD sequences were performed by FGENESH (http://linux1.softberry.com/) using Eukaryotic gene finder module [19]. The active sites of the transcripts were predicted by Prosite online server of ExPasy [20] (https://prosite.expasy.org/). The motifs of secondary protein structure were created by PDBsum using v.3.0 of Gail Hutchinson's PROMOTIF program [21]. The created motifs were then used for 3D modelling and structure prediction. CHS and SOD exist in the homodimer state in the cell, therefore, the 3D models were predicted using homology-based modelling by SWISS-MODEL (https://swissmodel.expasy.org/) using default parameters [22]. The 3D structures and predicted models were visualized using UCSF Chimera v.1.13.1 software [23]. The energy minimized models were used for generation of Ramachandran plot of the proteins using PDBsum server (http://www.ebi.ac.uk/thornton- 
srv/databases/pdbsum). In order to calculate physicochemical properties of the protein sequences of both proteins, CHS and SOD Protparam software was used (http://web.expasy.org/protparam/). The QMEAN server (https://swissmodel.expasy.org/qmean/) was used to find the overall quality of 3D structure [24]. The 3D model for ligand (CBH-C) cellobiohydrolase-c was predicted using SWISS-MODEL and structure analysis was carried out as above mentioned. The protein-protein docking was performed by FRODOCK version 2.0 for Interactive protein-protein docking [25]. Further simulation study was carried out using online server GRAMM-X Protein-Protein Docking Web Server v.1.2.0 by Vakser Lab (http://vakser.compbio.ku.edu/resources/gramm/grammx/index_html) to check their all possible interactions [26].

\section{Abbreviations}

APX: Ascorbate peroxidase; SOD: Superoxide dismutase; CHS: Chalcone synthase; CHT: Chitinase; cDNA: Complementary DNA; DNA: Deoxyribonucleic acid; RNA: Ribonucleic acid; NTC: Non-template control; qPCR: Quantitative real-time polymerase chain; RNA: Ribonucleic acid; USA: United States of America; NCBI: National Center for Biotechnology Information; SMD: Sterility mosaic disease; PR: Pathogenesis related; ToMV: Tomato mosaic virus; DI: Disease Incidence; FU: Fusarium udum; FYM: Farm yard manure; AO: Antioxidant: TP: Time point; CDS:Coding sequences; ORF: Open reading frame; CDD: Conserved domains database; Integrated DNA Technologies: IDT; BLAST: Basic Local Alignment Search Tool; CBH-C:Cellobiohydrolase-C; IFR:Isoflavone reductase, MSR:Methionine sulphoxide reductase B2, GTF:Glycosyl transferase,GPX: Glutathione peroxidase; EtBr: Ethidium bromide; ROS: Reactive oxygen species; UGC: University Grants Commission; ICRISAT: International Crops Research Institute for the Semi-Arid Tropics; ICM: Integrated Crop Management.

\section{Declarations}

Ethics approval and consent to participate-This research article does not contain any studies with human participants or animals performed by any of the authors.

Consent for publication-This research paper does not contain any individual's personal data in any form.

Availability of data and materials-This research paper has cited the relevant references as necessary.

Competing interest-The authors do not have competing interest.

Funding. This study was financially supported by UGC Emeritus Fellowship funded by UGC at Kalyani University, West Bengal, India for the entire research program.

Author contributions. PDG, KB and MS conceived the idea and designed the study. KB performed the experiments. KB, RK, AT, VG, NS, SP and PS analyzed the data with the input from KB. KB, PS,AT and SP wrote the manuscript.

Acknowledgments. Authors are also thankful to Dr. Mamta Sharma, Principal Scientist and Head of ICM, ICRISAT, Hyderabad, India for providing biological samples and excellent guidance.

\section{References}

1. Allen DJ, Lenné JM. The pathology of food and pasture legumes. CAB International. 1998; 35:507-516.

2. Pande S, Sharma M, Mangla UN, Ghosh R, Sundaresan G. Phytophthora blight of Pigeonpea Cajanus cajan (L.) Mill sp.]: An updating review of biology, pathogenicity and disease management. Crop Protection. 2011;30(8):951-7.

3. Dangi AK, Sharma B, Khangwal I, Shukla P. Combinatorial interactions of biotic and abiotic stresses in plants and their molecular mechanisms: systems biology approach. Mol. Biotechnol. 2018;25:1-5.

4. Pande S, Sharma M, Avuthu N, Telangre R. High Throughput Phenotyping of Chickpea Diseases: Stepwise Identification of Host Plant Resistance. Information Bulletin No. 92. International Crops Research Institute for Semi-Arid Tropics; 2012;PP40

5. Okiror MA. Genetics of resistance to Fusarium udum in pigeonpea [Cajanus cajan (L.) Mill sp.]. Indian J Genet PI Br. 2002;62(3):218-20.

6. Joshi S. Pathogenic variability in Pigeonpea wilt pathogen Fusarium udum butler in Nepal. Nepal Agriculture Research Journal. 2001:64-5.

7. Srivastava R, Sharma A, Tiwari P, Singh A, Saxena AK. First de novo draft genome sequence of the pathogenic fungus Fusarium udum F02845, associated with pigeonpea (Cajanus cajan L. Millspaugh) wilt. Microbiol Resour Announc 2018;7:e01001-18.

https://doi.org/10.1128/MRA.01001-18.

8. Madhukeshwara SS, Seshadri VS, Mantur SG, Babu HN. Screening of pigeonpea genotypes for Fusarium-wilt resistance. J. Mycopathol. Res. 2004;42(2):185.

9. Butt UR, Naz R, Nosheen A, Yasmin H, Keyani R, Hussain I, Hassan MN. Changes in pathogenesis-related gene expression in response to bioformulations in the apoplast of maize leaves against Fusarium oxysporum. J. Plant Interact. 2019;14(1): 61-72. 
10. Saikia R, Singh BP, Kumar R, Arora DK. Detection of pathogenesis-related proteins-chitinase and $\beta-1$, 3-glucanase in induced chickpea. Curr Sci. 2005:659-63.

11. Gupta S, Bhar A, Chatterjee M, Das S. Fusariumoxysporumf. sp. ciceri race 1 induced redox state alterations are coupled to downstream defense signaling in root tissues of chickpea (Cicer arietinum L.). PLoS One. 2013;8(9):e73163.

12. Andolfo G, Ferriello F, Tardella L, Ferrarini A, Sigillo L, Frusciante L, Ercolano MR. Tomato genome-wide transcriptional responses to Fusarium wilt and Tomato Mosaic Virus. PloS one. 2014;9(5):e94963.

13. Liu B, Xue X, Cui S, Zhang X, Han Q, Zhu L, Liang X, Wang X, Huang L, Chen X, Kang Z. Cloning and characterization of a wheat $\beta-1$, 3glucanase gene induced by the stripe rust pathogen Puccinia striiformis f. sp. tritici. Molecular Biology Reports. 2010; $37(2): 1045$.

14. Altschul S, Gish W, Miller W, Myers E, Lipman D. Basic local alignment search tool. Journal of Molecular Biology. 1990; 215(3): 403410. doi:10.1016/s0022-2836(05)80360-2.

15. Thompson JD, Higgins DG, Gibson TJ. CLUSTAL W: improving the sensitivity of progressive multiple sequence alignment through sequence weighting, position-specific gap penalties and weight matrix choice. Nucleic acids res. 1994;(22): 4673-80.

16. Biswas K, Ghosh P. Optimization of an efficient RNA isolation protocol from Fusarium wilted pigeonpea plant (Cajanus cajan(L.) Millspaugh). Intl. J. Biochem. Res. Rev. 2016;12:1-10. (doi:10.9734/IJBCRR/2016/25978).

17. Sinha P, Singh VK, Suryanarayana V, Krishnamurthy L, Saxena RK, Varshney RK. Evaluation and validation of housekeeping genes as reference for gene expression studies in pigeonpea (Cajanus cajan) under drought stress conditions. PloS one. 2015;10(4):e0122847.

18. Livak KJ, Schmittgen TD. Analysis of relative gene expression data using real-time quantitative PCR and the $2^{-\triangle \Delta} \mathrm{CT}$ method. Methods. 2001 ; 25(4): 402-408.

19. Solovyev V, Kosarev P, Seledsov I, Vorobyev D. Automatic annotation of eukaryotic genes, pseudogenes and promoters. Genome Biol. 2006;7:1-3. (doi:10.1186/gb-2006-7-s1-s10).

20. Gasteiger E, Gattiker A, Hoogland C, Ivanyi I, Appel RD, Bairoch A. ExPASy: The proteomics server for in-depth protein knowledge and analysis. Nucleic Acids Res. 2003;31(13):3784-3788. (doi:10.1093/nar/gkg563).

21. Laskowski RA. PDBsum: summaries and analyses of PDB structures. Nucleic Acids Res. 2001; 29(1):221-222. (doi:10.1093/nar/29.1.221).

22. Waterhouse, A., Bertoni, M., Bienert, S., Studer, G., Tauriello, G., Gumienny, R., Heer, F.T., de Beer, T.A.P., Rempfer, C., Bordoli, L., Lepore, R., Schwede, T. SWISS-MODEL: homology modelling of protein structures and complexes. Nucleic Acids Res. 2018; 46: W296-W303.

23. Pettersen, E.F., Goddard, T.D., Huang, C.C., Couch, G.S., Greenblatt, D.M., Meng, E.C., and Ferrin, T.E. "UCSF Chimera - A Visualization System for Exploratory Research and Analysis." J. Comput. Chem. 2004; 25:1605-1612.

24. Benkert, P., Biasini, M., Schwede, T. Toward the estimation of the absolute quality of individual protein structure models. Bioinformatics. 2011; 27:343-350.

25. Garzon JI, Lopéz-Blanco JR, Pons C, et al. FRODOCK: a new approach for fast rotational protein-protein docking. Bioinformatics. 2009;25(19):2544-2551. (doi:10.1093/bioinformatics/btp447).

26. Tovchigrechko A, Vakser IA. GRAMM-X public web server for protein-protein docking. Nucleic Acids Res. 2006; 34:W310-4.

27. Hatsch D, Phalip V, Jeltsch JM. Use of genes encoding cellobiohydrolase-C and topoisomerase II as targets for phylogenetic analysis and identification of Fusarium. Research in Microbiology. 2004; 155(4):290-296.

28. Singh RS. Plant disease. 2009 Oxford and IBH Publishing.pp61-69.

29. Kannaiyan J, Nene YL, Reddy MV, Ryan JG, Raju TN. Prevalence of pigeonpea diseases and associated crop losses in Asia, Africa and the Americas. International Journal of Pest Management. 1984;30(1):62-72.

30. Reddy MV, Raju TN, Sharma SB, Nene YL, McDonald D, Pande S, Sharma M. Handbook of Pigeonpea Diseases (Revised). Information Bulletin No. 42. International Crops Research Institute for the Semi-Arid Tropics; 2012.

31. Gwata ET, Silim SN, Mgonja M. Impact of a new source of resistance to Fusarium wilt in pigeonpea. Journal of Phytopathology. 2006;154(1):62-64.

32. Chavan PN, Gahukar KB, Raut BT. Reaction of pigeonpea cultivars/lines of fusarium wilt in wilt sick plot. Research Journal-punjab rao krishi vidyapeeth. 1995;19:200-1.

33. Butler EJ. Selection of pigeonpea for wilt disease. Agricultural Journal of India. 1908;3:182-183.

34. Dhar V, Reddy MV, Chaudhary RG. Major diseases of pigeonpea and their management. Advances in Pigeonpea Research. 2005:229-61.

35. Karimi R, Owuoche JO, Silim SN. Importance and management of Fusarium wilt (Fusariumudum Butler) of pigeonpea. Intl. J. Agron. Agric. Res. 2012;2:1-4.

36. Ebrahim S, Usha K, Singh B. Pathogenesis related (PR) proteins in plant defense mechanism. Sci Against MicrobPathog. 2011;2:1043-54.

37. Gutiérrez N, Giménez MJ, Torres AM, Atienza SG, Ávila CM, Palomino C. Up-regulation of resistance gene analogs (RGA) in chickpea in the early response to Fusarium wilt. Euphytica. 2012;186(3):793-804. 
38. Nagy NE, Fossdal CG, Krokene P, Krekling T, Lönneborg A, Solheim H. Induced responses to pathogen infection in Norway spruce phloem: changes in polyphenolic parenchyma cells, chalcone synthase transcript levels and peroxidase activity. Tree Physiology. 2004;24(5):505-15.

39. Tropf S, Kärcher B, Schröder G, Schröder J. Reaction mechanisms of homodimeric plant polyketide synthase (stilbenes and chalcone synthase). A single active site for the condensing reaction is sufficient for synthesis of stilbenes, chalcones, and 6'-deoxychalcones. J Biol Chem. 1995; 270(14):7922-8.

40. Dao TT, Linthorst HJ, Verpoorte R. Chalcone synthase and its functions in plant resistance. Phytochem Rev. 2011; 10(3):397-412. (doi:10.1007/s11101-011-9211-7).

41. Perry JJ, Shin DS, Getzoff ED, Tainer JA. The structural biochemistry of the superoxide dismutases. BiochimBiophysActa. 2010; 1804(2):245-262. (doi:10.1016/j.bbapap.2009.11.004).

\section{Tables}

Table 1 Details of the epidemiology of FW in surveyed pigeon pea cultivated areas under the districts along with major cultivated varieties.

\begin{tabular}{|c|c|c|c|c|}
\hline Sl.No & State & Districts & Tehsil /Village & DI \% \\
\hline . & \multirow[t]{6}{*}{ Andhra Pradesh } & Warangal & Kamalapuram & 10.66 \\
\hline . & & Warangal & Ramnagar & 12.33 \\
\hline 3. & & Warangal & Shakapur & 4.66 \\
\hline . & & Medak & Ismailkhanpet & 8.55 \\
\hline 5. & & Medak & Nandikandi & 15.89 \\
\hline 5. & & Medak & Arur & 7.24 \\
\hline . & \multirow[t]{6}{*}{ Tamil Nadu } & Krishnagiri & Doddooru & 5.60 \\
\hline 3. & & Krishnagiri & BheemanakPalli & 10.8 \\
\hline 8. & & Krishnagiri & Andipatti & 13.25 \\
\hline 10. & & Dharmapuri & Perayambetti gate & 4.50 \\
\hline 11. & & Dharmapuri & Periyampatti & 12.88 \\
\hline 12. & & Dharmapuri & Baisalyae & 6.66 \\
\hline 13. & \multirow[t]{10}{*}{ Madhya Pradesh } & Dhar & Dharampuri & 15.6 \\
\hline 14. & & Dhar & Manawar & 10.2 \\
\hline 15. & & Dhar & Kukshi & 13.0 \\
\hline 16. & & Khargon & Maheshwar & 14.5 \\
\hline 17. & & Khargon & Mandleshwar & 8.6 \\
\hline 18. & & Khargon & Sanawad & 23.8 \\
\hline 19. & & Khargon & Bhikangaon & 5.0 \\
\hline 20. & & Barwani & Julwania & 8.5 \\
\hline 21. & & Barwani & Anjad & 26.0 \\
\hline 22. & & Barwani & Rajpur & 19.0 \\
\hline 23. & \multirow[t]{3}{*}{ West Bengal } & Murshidabad & Nabagram & 18.1 \\
\hline 24. & & Nadia & Birohi & 15.6 \\
\hline 25. & & Murshidabad & Karimpur & 10.0 \\
\hline
\end{tabular}

Table 2 Details of pigeonpea seeds collected from different pigeonpea growing areas of Indian states and screening data (\%DI) based on disease reaction used for genotype evaluation against FW. Here R represents Replication.

\begin{tabular}{|c|c|c|c|c|c|c|c|c|c|c|c|}
\hline Code & Landrace /Variety & Collection area & State & R1(6) & R2(6) & R3(6) & R4(6) & R5(6) & D.I (\%) & Disease reaction \\
\hline 1 & Richa & Local Farmer's collection & Madhya Pradesh & 0 & 2 & 1 & 0 & 0 & 10.0 & Resistant \\
\hline 2 & Grider & Local Farmer's collection & Madhya Pradesh & \multicolumn{4}{|c|}{ Nonviable seeds } \\
\hline 3 & Desi Nimar & Local Farmer's collection & Madhya Pradesh & 3 & 1 & 1 & 1 & 1 & 23.3 & Susceptible \\
\hline 4 & Parwati & Local Farmer's collection & Madhya Pradesh & 6 & 5 & 5 & 6 & 5 & 90.0 & Highly Susceptible \\
\hline 5 & Desi Tur & Local Farmer's collection & Madhya Pradesh & 6 & 4 & 5 & 4 & 5 & 80.0 & Highly Susceptible \\
\hline 6 & ICP-8863 & ICRISAT, Patancheru (Experimental control) & Telengana & 0 & 0 & 0 & 1 & 0 & 3.33 & \multicolumn{2}{|c|}{ Resistant } \\
\hline 7 & ICP-2376 & ICRISAT, Patancheru (Experimental control) & Telengana & 5 & 5 & 6 & 6 & 5 & 90.0 & Highly Susceptible \\
\hline 8 & WB-20/105 & PORS, Baharampur, W.B & West Bengal & 1 & 1 & 4 & 6 & 6 & 60.0 & Highly Susceptible \\
\hline
\end{tabular}


'able 3:Defense related gene sequences retrieved from NCBI databases forin-silicobased screening of biotic stress responsive genes.

\begin{tabular}{|c|l|l|l|l|l|l|}
\hline Sl. No. & \multicolumn{1}{|c|}{ Gene Name } & Accession number & Plant Source & Sequence type & Sequence length(bp) & CDS size (bp) \\
\hline 1 & GroES2 & DQ889509 & Ground nut & Partial & 736 & 606 \\
\hline 2 & Chalcone synthase & AJ012690 & Chickpea & Full Length & 1375 & 1170 \\
\hline 3 & Isoflavone reductase & XM004512368 & Chickpea & Full Length & 1156 & 936 \\
\hline 4 & Methionine sulphoxide reductase & XM003608291 & Barrelclover & Full Length & 862 & 570 \\
\hline 5 & Glycosyl transferase & NM001249894 & Soybean & Full Length & 1990 & 1476 \\
\hline 6 & Chitinase & X70660 & Chickpea & Full Length & 1077 & 882 \\
\hline 7 & B1, 3 glucanase & NM001279135 & Chickpea & Full Length & 1261 & 996 \\
\hline 8 & Osmotin & AB370233 & Soybean & Full Length & 909 & 723 \\
\hline 9 & Protease & XM_00363 & Barrelclover & Full Length & 1473 & 1473 \\
\hline 10 & Ascorbate peroxidase & FJ914865 & Chickpea & Full Length & 1030 & 840 \\
\hline 11 & Glutathione peroxidase & DQ889534 & Peanut & Full Length & 703 & 648 \\
\hline 12 & Superoxide dismutase & AJ012739 & Chickpea & Full Length & 702 & 459 \\
\hline
\end{tabular}

Table 4 List of selected primers used for RT-PCR based identification and qPCR based expression analysis of biotic stress responsive genes.

\begin{tabular}{|c|c|c|c|c|c|c|c|c|c|}
\hline \multirow{2}{*}{$\begin{array}{l}\text { S. } \\
\text { No. }\end{array}$} & \multirow{2}{*}{$\begin{array}{l}\text { Primer } \\
\text { Name } \\
\text { (Gene) }\end{array}$} & \multicolumn{4}{|c|}{ Oligos for RT-PCR } & \multicolumn{4}{|c|}{ Oligos for qPCR } \\
\hline & & $\begin{array}{l}\text { Gene } \\
\text { Code }\end{array}$ & $\begin{array}{c}\text { Forward (For) and Reverse (Rev) } \\
\text { Sequence }\left(5^{\prime}-3^{\prime}\right)\end{array}$ & Length & $\begin{array}{l}\text { Amplicon } \\
\text { Size (bp) }\end{array}$ & Code & $\begin{array}{c}\text { Forward (For) and Reverse } \\
\text { (Rev) } \\
\text { Sequence }\left(5^{\prime}-3^{\prime}\right)\end{array}$ & Length & $\begin{array}{l}\text { Amplicon } \\
\text { Size (bp) }\end{array}$ \\
\hline 1 & $\begin{array}{l}\text { Chalcone } \\
\text { synthase } \\
\text { Forward }\end{array}$ & $\begin{array}{l}\text { CHS- } \\
\text { For }\end{array}$ & TTGGATGCTAGGCAAGACATGGTGGT & 26 & 561 & $\begin{array}{c}\text { qCHS- } \\
\text { F }\end{array}$ & GCTTCGTTTGGCCAAGGATTTG & 22 & 96 \\
\hline 2 & $\begin{array}{l}\text { Chalcone } \\
\text { synthase } \\
\text { Reverse }\end{array}$ & $\begin{array}{l}\text { CHS- } \\
\text { Rev }\end{array}$ & CTTTGAGACAATCCCAGGAACATC & 24 & & $\begin{array}{c}\text { qCHS- } \\
\text { R }\end{array}$ & CTTGGGCCACGGAATGTGACAG & 22 & \\
\hline 3 & $\begin{array}{l}\beta 1,3 \\
\text { glucanase- } \\
\text { Forward }\end{array}$ & $\begin{array}{l}\text { B1.3G- } \\
\text { For }\end{array}$ & ACGGTCTCGATATCGCTGTTAG & 22 & 453 & $\begin{array}{c}\text { qB13G- } \\
\text { F }\end{array}$ & CCTACGCTAACGACCAACAA & 20 & 129 \\
\hline 4 & $\begin{array}{c}\beta 1,3 \\
\text { glucanase- } \\
\text { Forward }\end{array}$ & $\begin{array}{l}\text { B1.3G- } \\
\text { Rev }\end{array}$ & GTGAGTTGTCAAATATAAGAGGGTCTG & 27 & & $\begin{array}{c}\text { qB13G- } \\
\text { R }\end{array}$ & CTTTCTCGAGAGCAGCGTATAG & 22 & \\
\hline 5 & $\begin{array}{l}\text { Ascorbate } \\
\text { peroxidase- } \\
\text { Forward }\end{array}$ & $\begin{array}{l}\text { APX- } \\
\text { For }\end{array}$ & CTGGGACTATTAACTTCAGTCAGG & 24 & 354 & qAPX-F & TAACTGGTGGACCCGAAGTA & 20 & 121 \\
\hline 6 & $\begin{array}{l}\text { Ascorbate } \\
\text { peroxidase- } \\
\text { Reverse }\end{array}$ & $\begin{array}{l}\text { APX- } \\
\text { Rev }\end{array}$ & CCCAATAATACCACAAGCTACTCT & 24 & & $\begin{array}{c}\text { qAPX- } \\
\text { R }\end{array}$ & TTGCCGAACACATCCCTAAG & 20 & \\
\hline 7 & $\begin{array}{l}\text { Superoxide } \\
\text { dismutase- } \\
\text { Forward }\end{array}$ & $\begin{array}{l}\text { SOD- } \\
\text { For }\end{array}$ & TCCTAGGTGTCTCAAATGATGC & 22 & 404 & $\begin{array}{c}\text { qSOD- } \\
\text { F }\end{array}$ & GGAGCACATTTCAATCCTAATGG & 23 & 95 \\
\hline 8 & $\begin{array}{l}\text { Superoxide } \\
\text { dismutase- } \\
\text { Reverse }\end{array}$ & $\begin{array}{l}\text { SOD- } \\
\text { Rev }\end{array}$ & GGTACCCAACTTCATTATTTCCTTG & 25 & & $\begin{array}{c}\text { qSOD- } \\
\text { R }\end{array}$ & CCGACATTGACATTCCCTAGAT & 22 & \\
\hline
\end{tabular}

\section{Figures}


FU stress imposition
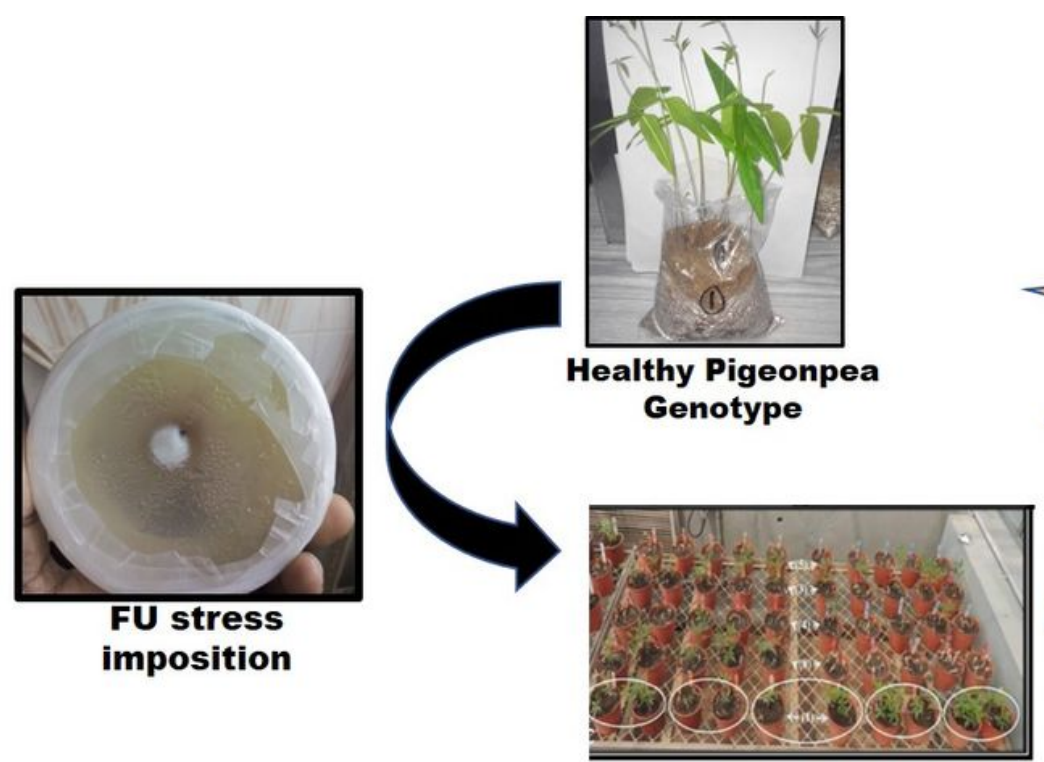

Pathogenicity Test

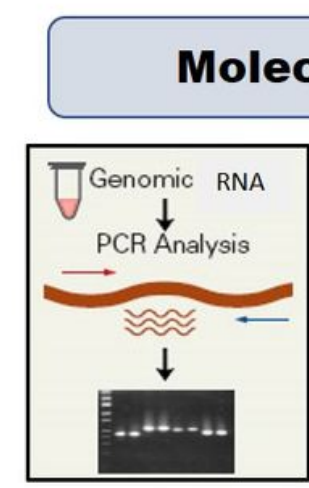

Transcriptional gene detection

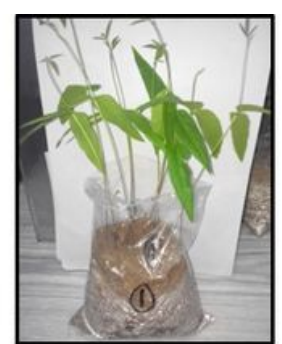

Healthy Pigeonpea Genotype

Pathogenicity Test

\section{ular Biology Studies}

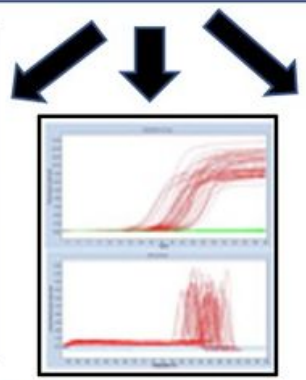

qPCR based gene expression study

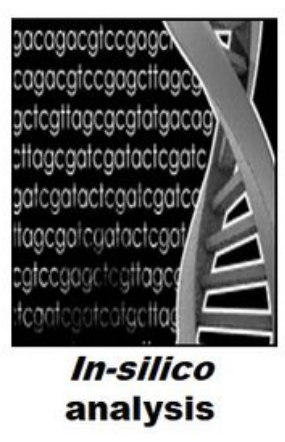

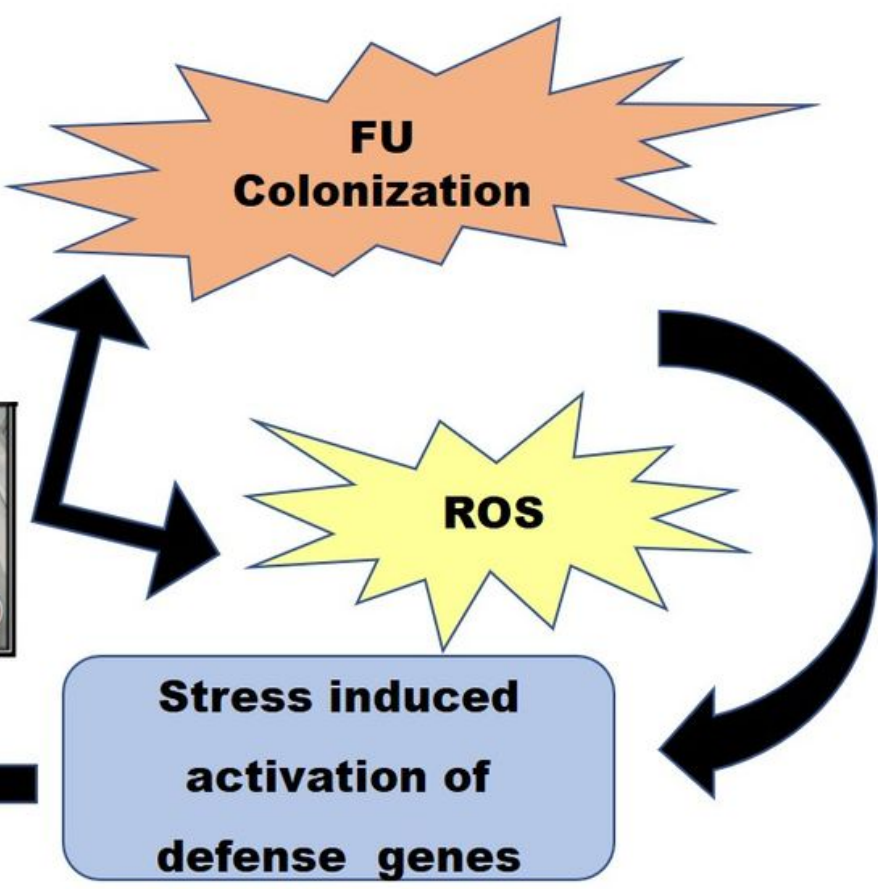
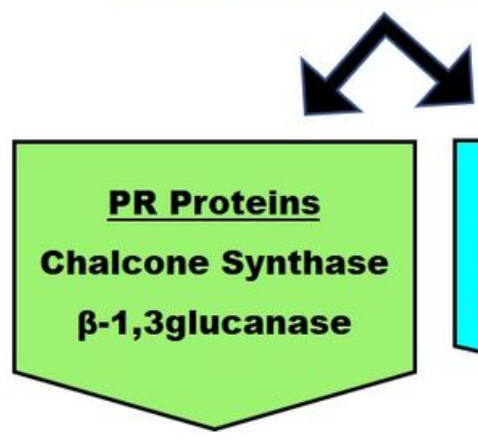

Antioxidant genes Ascorbate peroxidase Superoxide dismutase

Figure 1

Schematic representation of the linking pathways between present study and molecular pathogenesis of F. udumconcomitant with ROS regeneration and PR protein induction. 


\begin{tabular}{|l|l|l|l|}
\hline Sl. No. & \% of D.I Range & Grading & Tagging color \\
\hline 1. & $0.1-5.0$ & Very less infested area & Off-white \\
\hline 2. & $5.1-10.0$ & Less infested area & Sky \\
\hline 3. & $10.1-15.0$ & Moderately infested area & Yellow \\
\hline 4. & $15.1-20.0$ & Highly infested area & Green \\
\hline 5. & 20.1 & Very highly infested area & Orange \\
\hline
\end{tabular}

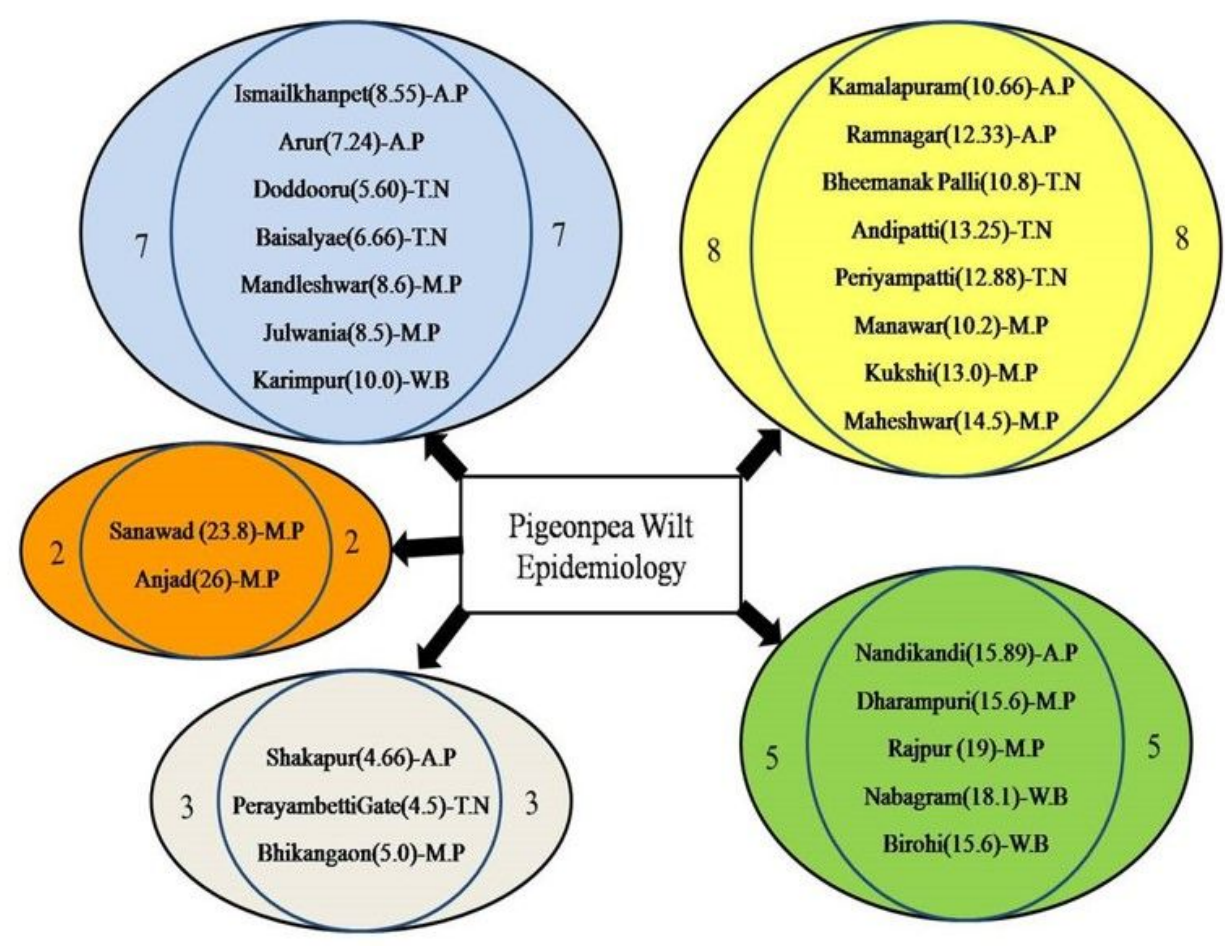

Figure 2

Scattered oval diagram of epidemiological intensity of Fusarium wilt disease in different surveyed districts of Indian states. Epidemiological grading of surveyed areas based on $\% \mathrm{DI}$ and their related tagging in the diagram. 

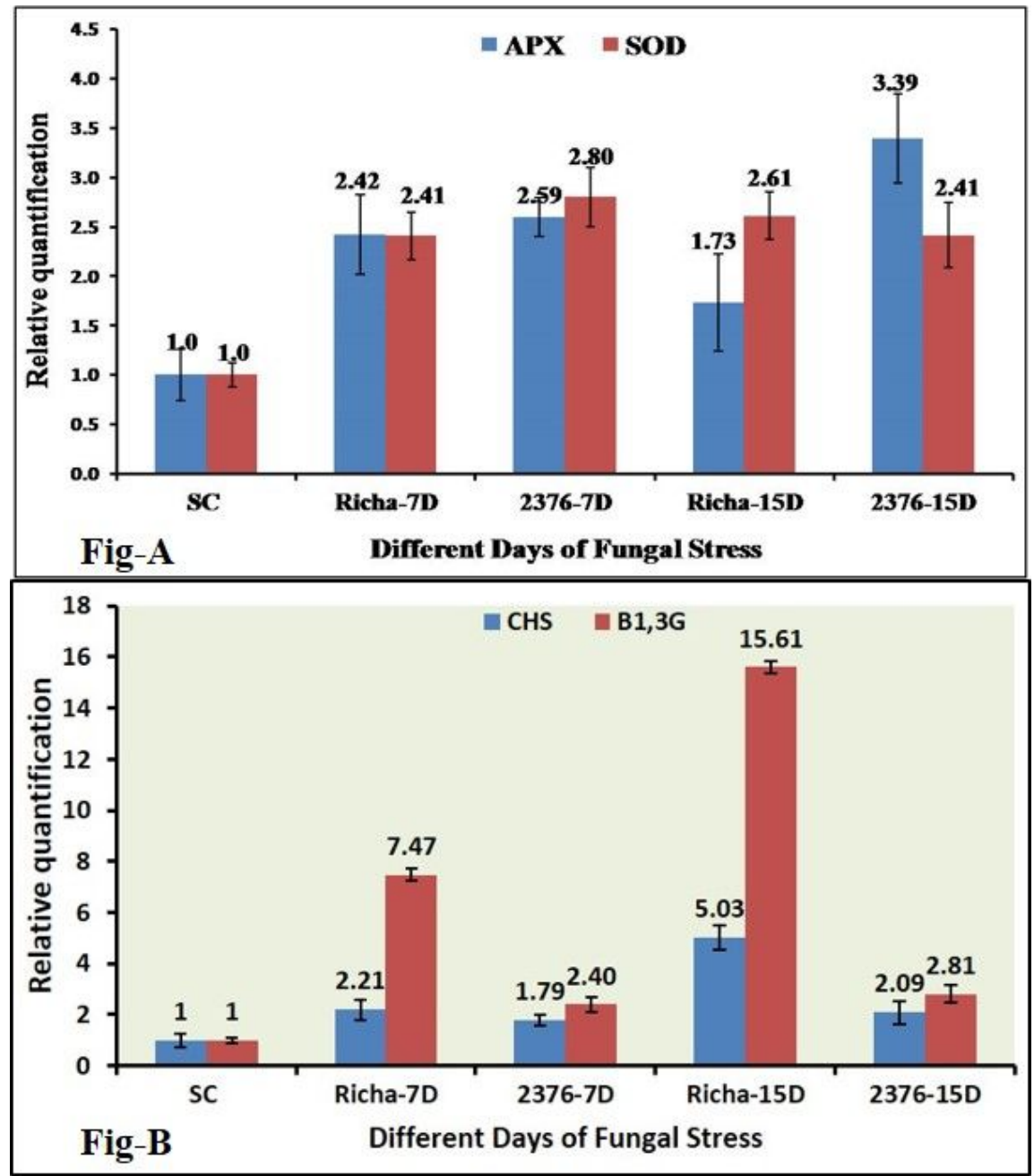

Figure 3

qPCR based comparative expression pattern analysis of (A) two antioxidant genes (APX \& SOD), (B) two Pathogenesis Related genes (CHS\& $\beta-1,3-G l u)$ under FU infection in two pigeonpea genotypes; SC-ICP2376 as Susceptible Control, 7D-7Days After Inoculation, 15D-15Days. After Inoculation, Richa-Genotype of unknown response, 2376-Susceptible variety. 

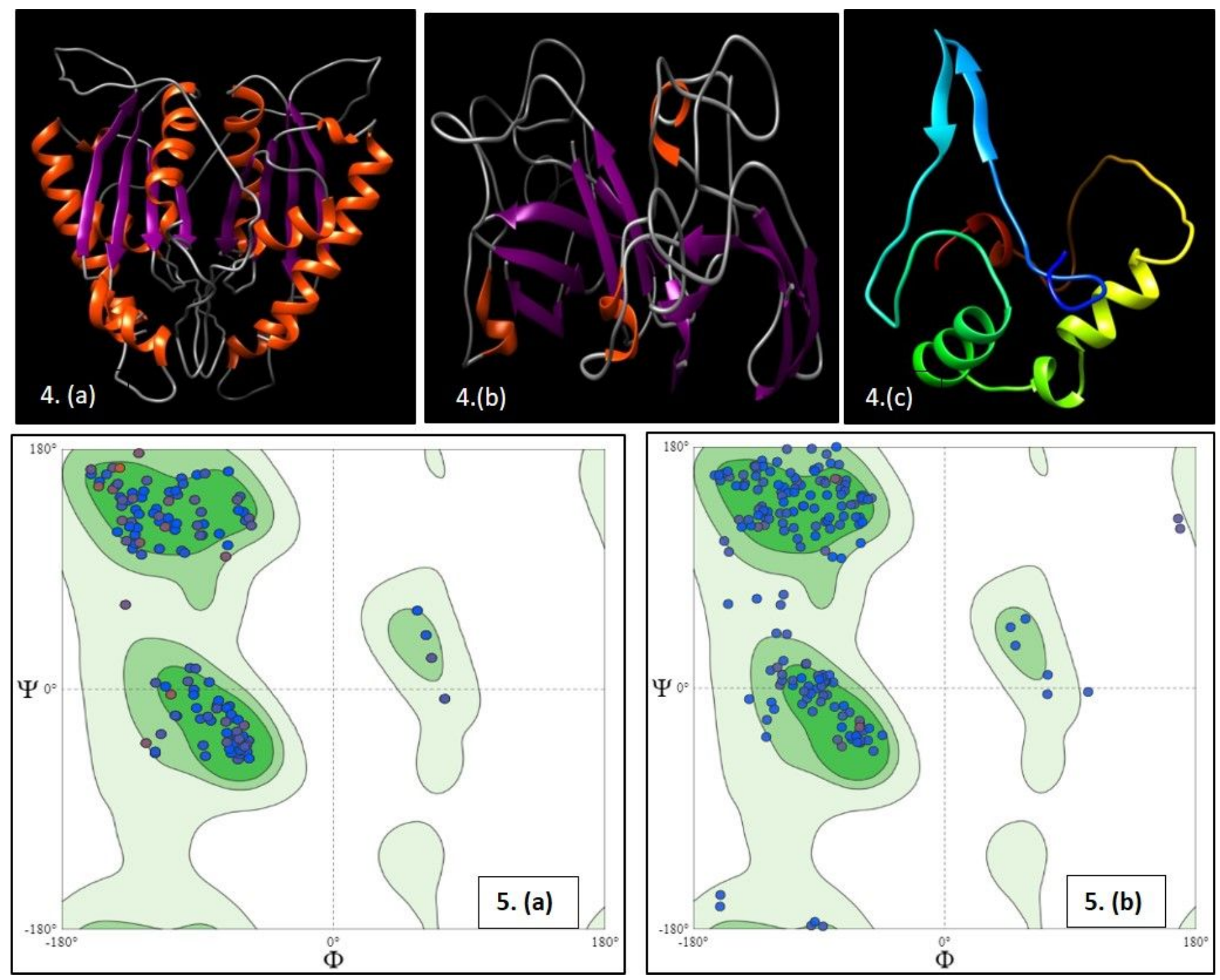

Figure 4

3D Model of protein CHS (a) and SOD (b) represented as ribbon models. Two similar chains represent the homodimer state of the proteins in the cell. The orange color represents $\beta$ helix and purple color represents the strands. (c) 3D model of ligand $\mathrm{CBH}-\mathrm{C}$ representing residue composition. Ramachandran plot of 3D structure for (d) CHS and (e) SOD. 

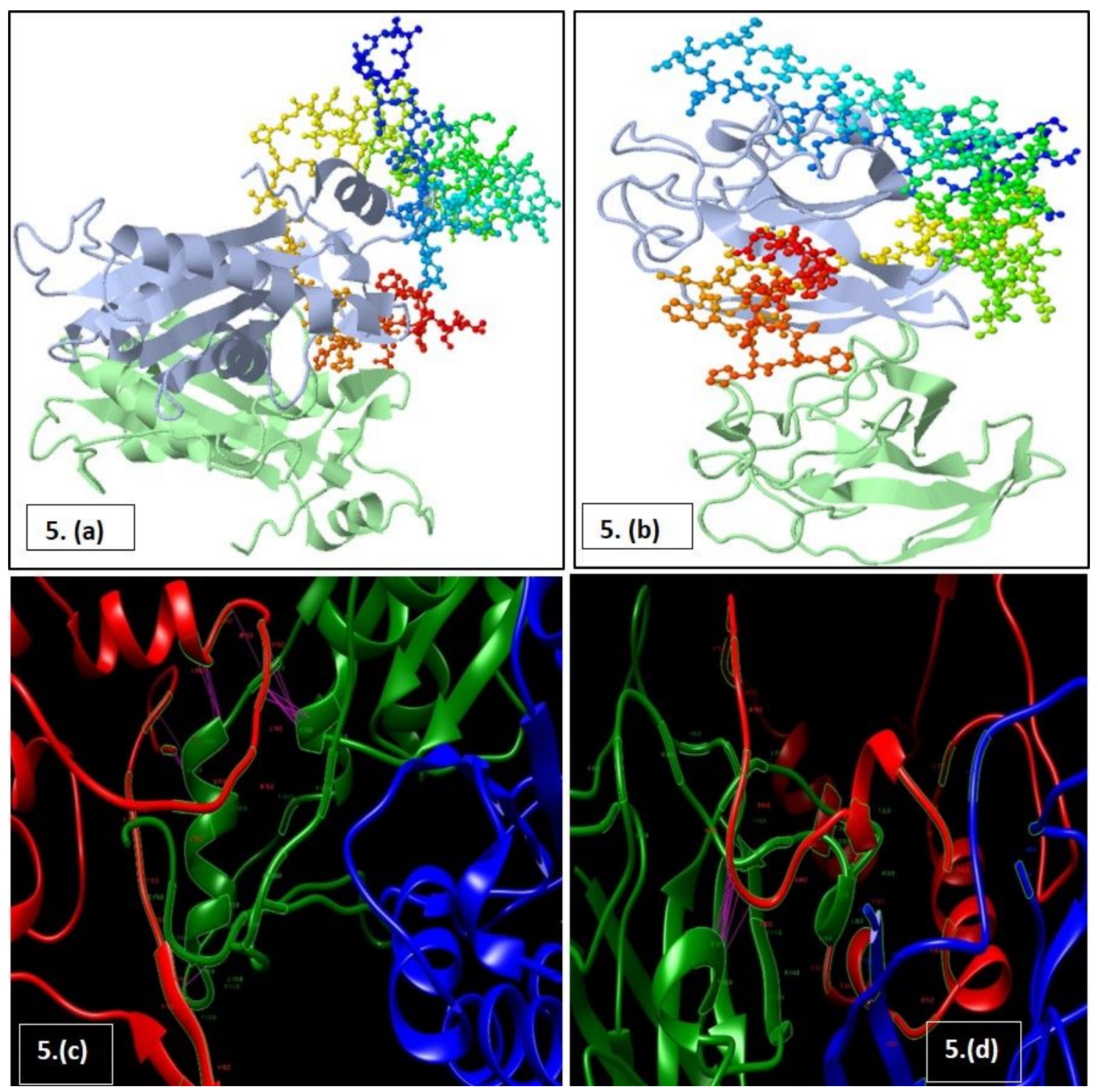

Figure 5

Docking of predicted 3D models. (a) Docking of $\mathrm{CBH}-\mathrm{C}$ with Chalcone synthase (CHS) and (b) Docking of $\mathrm{CBH}-\mathrm{C}$ with Superoxide dismutase (SOD). The receptors (CHS and SOD) are represented as ribbon and ligand ( $\mathrm{CBH}-\mathrm{C})$ represented as ball and stick model colored based on residues.Docking Simulation studies showing the clashes and contact between the receptor and ligand molecule. The pink line represents the contact. Red ribbon structure is $\mathrm{CBH}-\mathrm{C}$ whereas green and blue ribbons represent the homodimer chains of $\mathrm{CHS}$ (c) and SOD (d).

\section{Supplementary Files}

This is a list of supplementary files associated with this preprint. Click to download.

- Methodsformula.docx

- Sup.Fig.1.jpg

- Additionalfile2.pdf

- Sup.Fig.2.jpg

- Additionalfile1.pdf 